Research Article

\title{
Rodent Control a Tool for Prevention of Leptospirosis - A Success Story on Human Leptospirosis with Gujarat State
}

\author{
AMKMohan Rao
}

Consultant, National Institute of Rural Development, Rajendranagar, Hyderaabad and Former Joint Director, National Institute of Plant Health Management, Department of Agriculture \& Cooperation, Ministry of Agriculture Rajendranagar, Hyderabad, Telangana, India.

DOI: https://doi.org/10.24321/0019.5138.202028

\section{I $\quad \mathbf{N} \quad \mathbf{F} \quad \mathbf{O}$}

E-mail Id:

mohanrao.arasada@live.com

Orcid Id:

https://orcid.org/0000-0002-3127-3496

How to cite this article:

Rao AMKM. Rodent Control a Tool for Prevention of Leptospirosis - A Success Story on Human Leptospirosis with Gujarat State. J Commun Dis 2020; 52(3): 38-42.

Date of Submission: 2020-03-12

Date of Acceptance: 2020-05-19

\section{$\begin{array}{llllllll}\mathbf{A} & \mathbf{B} & \mathbf{S} & \mathbf{T} & \mathbf{R} & \mathbf{A} & \mathbf{C} & \mathbf{T}\end{array}$}

Leptospirosis is a debilitating zoonosis for humans as well as domestic animals worldwide and widespread in tropical and sub tropical areas with high rainfall. India being a tropical country is potential for this debilitating disease. Among mammals, rodents are most important and widely distributed reservoirs of leptospiral infection. Four species of rodents i.e., Rattus norvegicus, Rattus rattus, Bandicota indica and Bandicota bengalensis, are known vectors for this disease and transmit the infection in rural and urban areas. Hence, rodent control in larger areas is recommended for preventing the spread of this disease. Gujarat is one of the States having established leptospirosis endemic pockets, particularly in Valsad, Navsari, Tapi and Surat districts. Hence, the Departments of Health and Agriculture, Gujarat conducted coordinated rodent vector control campaigns to prevent the disease spread. All activities were guided by National Institute of Plant Health Management, Hyderabad and funded under National Plan on Rodent Pest Management of Department of Agriculture and Cooperation, Ministry of Agriculture, Government of India. The initial pilot scale rodent control campaigns conducted in 114 villages covering 5,127 hectares jointly by Agriculture and Health Departments of the state in 2009 brought a reduction of $61 \%$ leptospirosis disease prevalence. Following this success, large scale community based rodent control campaigns were organized during 2012 in these districts in 1822 villages covering 4,70,782 hectares and obtained $82 \%$ reduction in the disease prevalence. It was observed that the inter-departmental coordination of Agriculture and Health Departments brought these significant results, which can be replicated and adopted elsewhere to prevent leptospirosis in the country.

Keywords: Leptospirosis, Disease, Rodents, Vector Control, Lesser Bandicoot 


\section{Introduction}

The Human Capital theory of 1960s denotes that preventing diseases and death increases the population efficiency (Schultz, 1961). Further, numerous sociological and economic studies also confirmed that much fertile land lay idle because of human diseases (WHO, 2002). Leptospirosis is one of the commonly occurring diseases highly prevailing in human populations, but most often remained undiognosed. As per the International Leptospirosis Society (ILS) report the disease occurs on an average of 100,000 worldwide (WHO, 1999), but is most common in tropical and sub tropical areas with high rainfall. It is an infectious disease caused by pathogenic bacteria, Leptospira that are transmitted directly or indirectly from animals to humans. It is recognized as an important cause of pulmonary haemorrhage syndrome and is one of the leading causes of morbidity worldwide and accounts for significant numbers of human deaths. It remained mostly as undiagnosed neglected disease affecting rural subsistence farmers working in irrigated crops like rice and sugarcane. Urban slum dwellers exposed to 'rodent urine contaminated sewage' are also vulnerable for the disease infection.

India has prevalence of this disease in many places with several States declared as endemic for this disease. Reports on outbreaks of leptospirosis exist from several coastal districts of the States viz., Gujarat, Maharashtra, Kerala, Tamil Nadu, Andhra Pradesh, Karnataka and Andamans from time to time (John, 1996; Joshi et al, 1999; Mathur et al, 2000; Muthusethupathi et al., 1985; Rao, 1996; WHO, $1999,2000)$. In addition, cases have also been reported in other areas like Goa and Orissa as a result of heavy rainfall and consequent flooding (WHO, 2000). The infections are maintained within these populations through vertical and horizontal transmission, and form the infection reservoir. They carry a particular strain of leptospira in their kidneys and shed them with their urine for long periods, and even for their lifespan, without causing any illness for them. Infected animals transfer leptospires to their offspring either in utero or during neonatal period, thereby making a chain of infection by the maintenance host.

\section{Permanent hosts (Reservoir)/ Vectors}

Important permanent (reservoir) hosts include small mammal species, notably field and peri-domestic rodents, insectivores like shrews and domestic animals like cattle, pigs and dogs (Anon, 1999).with rodents taking major role due to their commensal habits. Krishnappa and Moorthy (1999) reported 54\% serological prevalence of leptospirosis among rodents. Limited work in India indicated four rodent species i.e., Rattus norvegicus, $R$. rattus and Bandicota bengalensis, $B$. indica as associated with this disease (Gangadhar, 1999). Humans are dead end hosts and do not provide an infection reservoir. Considering these aspects, V Annual Congress of Indian Leptospirosis Society recommended rodent control measures to prevent the disease during 2005. It also specified that rodent control measures be organized on community scale by involving Government, Cooperatives and Panchayats (Rao, 1992). Hence, the impact of whole community involved rodent control campaigns in leptospirosis endemic districts were analyzed on the disease prevalence.

\section{Activities Undertaken before Rodent Vector Control}

\section{Selection of Districts and Villages for Community based Rodent Control}

South Gujarat comprising of Navsari, Surat, Tapi and Valsad districts have Sugarcane based cropping systems with sugarcane as major crop with rice and wheat (Rao, 2006). Rodents are major pests in Gujarat with their damage ranging from 10 to 30 percent (Vyas et al, 2000), especially during August and September months, and Sugar factories adopted various rodent control methods often with little success. The rodent damage is also spread to rice and wheat crops limiting the productivity of these major cereal crops. On the other hand, reports also exist on spread of human zoonoses transmitted by rodents viz., urban plague and leptospirosis (John, 1996). Although plague could be contained with various measures taken by Public Health department, the prevalence of leptospirosis increased in all the four South Gujarat districts after 2000 (Rao, 2003). Mostly farm workers were found to be vulnerable for this debilitating disease. Due to this, Government of Gujarat initiated various measures for medical management of the disease and also vector control. It is in this context, Health department was associated with Agriculture department for collaborating actions on anti rodent campaigns in these districts.

\section{Field Level Survey to Identify Rodent Vector Species}

Field level surveys by Vyas et al (2000) from 1988 indicated sugarcane as major crop in these districts and found to be infested mostly by lesser bandicoot, Bandicota bengalensis with their live burrows on the bunds as well as deep inside the sugarcane crop. Rice nurseries were also infested with $B$. bengalensis on bunds. Occasionally, burrows of Soft furred field rat, Millardia meltada were reported. In view of predominance of $B$. bengalensis in these districts, focused attention was given for controlling these lesser bandicoots in the study. Accordingly, plans were made for capacity enhancement, campaign planning and implementation for rodent vector control.

\section{Planning and Capacity Building}

Based on the request of the Director of Agriculture, Gujarat, National Institute of Plant Health Management (NIPHM), Hyderabad under Ministry of Agriculture, Government 
of India technically guided and coordinated with both Agriculture and Health Departments to undertake rodent control activities. Health Department conducted actions related to collection of serum samples from the farmers randomly in the villages for serological analysis, while the Department of Agriculture organized community based rodent control campaigns. Initially, NIPHM and Director of Agriculture, Government of Gujarat organized a State level Workshop cum Training on 5-6 January, 2009 for Macro Level planning anti rodent campaigns in the state involving both Agriculture and Health departments under Macro Management in Agriculture scheme of Government of India. Plans were drawn to enhance the capacity of concerned extension officers of Navsari, Surat, Tapi and Valsad districts to implement rodent control campaigns before the onset of monsoon.

First district level capacity enhancement program was conducted at Vyara on 9-10 June, 09 for 61 officers of Tapi and Surat Districts. The second program was conducted at Navsari on 12-13 June, 09 for 58 officers of Navsari and Valsad districts. These programs had both in-house discussion sessions and field activities on anti rodent campaigns. Officers of both Agriculture and Health departments participated supported by Regional Joint
Director of Agriculture and Regional Deputy Director of Health, Surat. During these capacity enhancement programs, villages with reported incidence of Leptospirosis as well as having history for the past 5-6 years were identified jointly by the participants of Health and Agriculture department. Micro level planning up to village level on the anti rodent campaigns was drawn in these programs and the Department of Agriculture implemented rodent control campaigns before the onset of the monsoon to prevent leptospirosis spread in these districts.

\section{Actual Rodent Vector Management}

\section{Focused Attention on Affected Villages and Timing}

Data provided for 2004-05 indicated that the Department of Agriculture initiated rodent control measures in 146 villages in Navsari district and 107 villages in Valsad district of Gujarat. However, 70 and 58 villages only were affected with leptospirosis disease in these two districts (Table 1). This clearly indicates the need for focused attention on villages affected with this disease than using the resources in villages not affected with the disease. It was also observed from the monthly disease incidence from 1997 to 2005 that the cases were reported only from July till October every year. This suggests the need for pre monsoon rodent control measures in these districts.

Table I.Particulars of villages with prevalence of leptospirosis in 2005 and villages treated for rodent control*

\begin{tabular}{|c|c|c|c|}
\hline S. No. & Particulars & Valsad district & Navsari district \\
\hline 1. & Total taluks in district & 5 & 5 \\
\hline 2. & No of most affected taluks & 5 & 2 \\
\hline 3. & Total no. of villages & 393 & 469 \\
\hline 4. & No of affected villages & 70 & 58 \\
\hline 5. & No. of cases reported & 114 & 88 \\
\hline 6. & No. of deaths & 26 & 11 \\
\hline 7. & No. of villages treated & 146 & 107 \\
\hline
\end{tabular}

*Data provided by the Health Department

Table 2. Particulars of pilot scale rodent control campaigns in Gujarat and impact on reduction of Leptospirosis prevalence during $\mathbf{2 0 0 9}$

\begin{tabular}{|c|c|c|c|c|c|c|}
\hline $\begin{array}{c}\text { Name of the } \\
\text { District }\end{array}$ & $\begin{array}{c}\text { Total no of } \\
\text { villages }\end{array}$ & $\begin{array}{c}\text { Villages } \\
\text { with lepto } \\
\text { prevalence } \\
\text { and covered }\end{array}$ & $\begin{array}{c}\text { Area treated with } \\
\text { bromadiolone } \\
\text { (Hectares) }\end{array}$ & $\begin{array}{c}\text { No of } \\
\text { Lepto cases } \\
\text { in 2008 }\end{array}$ & $\begin{array}{c}\text { No of Lepto } \\
\text { cases in } \\
\mathbf{2 0 0 9}\end{array}$ & $\begin{array}{c}\text { Reduction of } \\
\text { Lepto incidence } \\
\text { (\%) }\end{array}$ \\
\hline Surat & 407 & 43 & 7735 & 220 & 78 & 64.55 \\
\hline Tapi & 148 & 15 & 1050 & 133 & 40 & 69.92 \\
\hline Navsari & 397 & 18 & 444 & 131 & 43 & 67.18 \\
\hline Valsad & 178 & 38 & 1235 & 74 & 54 & 27.03 \\
\hline Total & 1130 & 114 & 10464 & 558 & 215 & 61.47 \\
\hline
\end{tabular}


Table 3.Particulars of rodent control campaigns in 4 districts of Gujarat and reduction of Leptospirosis prevalence during 2012

\begin{tabular}{|c|c|c|c|c|c|c|}
\hline \multirow{2}{*}{$\begin{array}{l}\text { Name of } \\
\text { District }\end{array}$} & \multirow{2}{*}{$\begin{array}{c}\text { Total } \\
\text { villages }\end{array}$} & \multirow{2}{*}{$\begin{array}{c}\text { No of Village } \\
\text { Covered }\end{array}$} & \multirow{2}{*}{$\begin{array}{c}\text { Area Treated with } \\
\text { Bromodiolone (Hectares) }\end{array}$} & \multicolumn{2}{|c|}{ Leptospirosis Cases in } & \multirow{2}{*}{$\begin{array}{c}\text { Reduction Of Lepto } \\
\text { indices (\%) }\end{array}$} \\
\hline & & & & 2011 & 2012 & \\
\hline Surat & 720 & 595 & 176748 & 329 & 33 & $296(89.96 \%)$ \\
\hline Tapi & 513 & 372 & 87595 & 293 & 73 & $220(75.08 \%)$ \\
\hline Navasari & 391 & 391 & 94239 & 156 & 28 & $128(82.05 \%)$ \\
\hline Valsad & 470 & 464 & 112200 & 119 & 18 & $101(84.87 \%)$ \\
\hline Total & 2094 & 1822 & 470782 & 897 & 152 & 745 (83.06\%) \\
\hline
\end{tabular}

\section{Rodent Control Campaigns with Anticoagulant Rodenticide}

With respect to rodent control campaigns, large scale community involved campaigns were planned at Micro level planning. The Surat Medical College and Surat Municipal Corporations also extended these micro planning exercises. Inter departmental coordination by Agriculture, Animal Husbandry and Health Departments have resulted in crisp implementation of these campaigns. Bromadiolone RB, a second generation anticoagulant rodenticide (Anon, 2004) as recommended under IPM practices in sugarcane based cropping systems was used in these campaigns under Macro Management Scheme in Agriculture, Government of India. As per the recommendation, Bromadiolone RB @ 400 g. was broadcasted in the fields per hectare as recommended by the Expert Committee on Rodent Control, Government of India. It is due to crop lodging and in-accessibility to the live burrows in the crop. However, residential premises were treated with Bromadiolone RB @ 100g per house. After deciding the dates for each village, large scale rodent control campaigns were organised in the affected villages involving whole community. Even no mans' lands, roads, canal bunds etc were also treated with the anticoagulant. Significant results were achieved with this anticoagulant baiting.

\section{Pilot Study in 2009}

A pilot study was made during 2009 covering an area of 10,511 hectares in 36 villages (Table 2). As a result, a reduction of $61 \%$ incidence in leptospirosis was achieved in these districts. The villages with reports on human leptospirosis came down from 91 to 36 as a result of the rodent control campaigns. However, the number of villages with leptospirosis reported increased from 36 to 122 in the following year i.e., 2010 in the absence of continuity in rodent control campaigns. The present result of lower level of success might be due to non coverage of entire area leaving pockets of lesser bandicoot infestations intermittently, leaving residential premises untreated and non coverage of no mans' lands etc.

\section{Community based Rodent Control Campaigns in 2012 and their Impact}

During 2012 rodent control campaigns were organized in 1822 villages out of 2894 total villages were selected (Table 3 ). These large scale rodent control campaigns covered $4,70,782$ hectares, which included poramboke land, roads, canal bunds etc. Comparison of the disease prevalence in 2011 and 2012 indicated a reduction of $83.06 \%$ human leptospiral incidence with a range of 82 to $90 \%$ in all the four districts. Even the villages with reports on human leptospirosis came down from 897 to 152 in campaign years in all the four districts. However, in the following year, i.e., 2013, an increase in the disease prevalence was observed to be $136 \%$ more than 2012 in the absence of any rodent control campaign. These results established that community involved rodent control campaigns could be one of the preventive measures for consideration to prevent leptospirosis incidence.

\section{Conclusions based on the Whole Community Approach}

\section{Surveillance Measures}

Surveillance serves the purpose in reducing disease incidence by proper planning activities for both the bacteria and vector management. This will facilitate focused attention in selecting villages with disease burden. During the surveys, sample collection of both rodent species as well as their infestation levels is required to be done. The sampling involves identification of the rodent species, collection of serum or tissues and transport of samples to the laboratory. The method established by Surat Municipal Corporation can be considered for surveillance system in which rodents are trapped periodically in identified areas of different blocks for identification of the species, to understand their level of infestation and for collection of sera and viscera for laboratory examination.

\section{Continuation of Rodent Vector Control Campaigns}

The $5^{\text {th }}$ Annual Congress of Indian Leptospirosis society, which met during 2005 at Surat recommended rat control 
measures on community scale on mission mode approach by involving Government, Corporate, Cooperatives and Panchayats for at least 5 to 10 years. However such recommendations of community based rodent control remained mostly on paper only. Multi-pronged approach is needed for such measures viz., time of control operations, focusing areas for treatment, appropriate technical knowhow, capacity building for concerned implementation staff, awareness creation among farming community and timely procurement and judicious use of inputs.

\section{Inter Departmental Coordination}

Multi pronged approach with different departments, viz., Agriculture and Health departments has yielded positive results through planning, coordination and evaluation. In order to prevent animal leptospirosis, Animal Husbandry Department also needs to collaborate with other Departments. Hence, for successful prevention of leptospirosis rodent vector control involving all concerned departments is highly essential and Gujarat has proved its need.

\section{Human Resource Development}

Human resources are desired to be developed among the technical personnel undertaking the rodent control practices for optimum results. It should be remembered that even minute left over rodent population could cause the disease through their urine. Community education through brochures, videotapes, warning signs, display boards, tee shirts etc.

\section{Acknowledgement}

The author is grateful to the Joint Secretary (Plant Protection), Ministry of Agriculture and Farmers Welfare, Government of India, New Delhi for funding under National Plan on Rodent Pest Management, and the Director General, National Institute of Plant Health Management for encouraging and supporting all activities for Gujarat State. Deep gratitude is extended to the Commissioner of Health and Director of Agriculture, Government of Gujarat, Gandhinagar for involving both Health and Agriculture departments on various activities of leptospirosis prevention in the state. Thanks are due to the Regional Deputy Director of Health, Surat for arranging serum sample collection and analysis, and Deputy Director of Agriculture (Pesticides), Directorate of Agriculture, Gandhinagar for assisting in coordinating the rodent control campaigns involving whole community in affected villages in all four districts of South Gujarat.

\section{Conflict of Interest: None}

\section{References}

1. Anon. Minutes of the meeting of $3^{\text {rd }}$ Expert Committee on Rodent Control. Government of India. 2004. 1-10.

2. Gangadhar NL. Rodents and leptospirosis: A global perspective. Proc. $1^{\text {st }}$ Natl Leptospirosis Conf., Bangalore. 1999; 11-13.

3. John TJ. Emerging and reemerging pathogens in India. Indian J Med Res 1996; 103: 4-18.

4. Joshi BA, Kagal A, Bharadwaj RS. Leptospirosis - a reemerging infection in Maharashtra. In: Proc. $1^{\text {st }}$ Natl. Leptospirosis Conf., Bangalore: 9. 1999.

5. Krishnappa G, Moorthy ARS. An anamnesis of leptospira research in Karnataka. Prof. $1^{\text {st }}$ National Leptospirosis Conference, Bangalore, 1-6. 1999.

6. Mathur RP, Radhakrishnan, Sivaprakasam J, Dhanraj C. Rodent control campaign in leptospirosis prone area in Chennai. Pestology 2000; 24: 74-80.

7. Muthusethupathi MA. Human leptospirosis - clinical manifestations. In: Proc. $1^{\text {st }}$ Natl Leptospirosis Conf, Bangalore. 1999; 1-6.

8. Nainan GK. Human Leptospirosis - Kerala experience. Proc. $1^{\text {st }}$ Leptospirosis Conference, Bangalore. 1999; 6-9.

9. Rao AMKM. Rodent control operations as a component of integrated pest management and the role of Government agencies in rodent pest management. Rodent Newsletter 1992; 16: 23-24.

10. Rao AMKM. Rodent problems in India and strategies for their management. In: Rats, Mice and People: Rodent Biology and Management (Eds. Singleton, GR., Krebs, CJ and Spratt, DM), ACIAR, Canberra. 2003; 229-232.

11. Rao AMKM. Preventive measures for Leptospirosis: Rodent Control. Indian J Medical Microbiology 2006; 24: 325-328.

12. Schultz TW. Investment in human capital. Am Econ Rev 1961; 52: 1-17.

13. Sehgal SC, Sugunan AP. Leptospirosis in Andamans. In: Proc $1^{\text {st }}$ Leptospirosis Conference, Bangalore. 1999; 5.

14. Vyas HJ, Kotadia VS, Butani PG. Glimpses of Research on Rodent Management in Gujarat (1988-1999). 2000; 1-74.

15. WHO. Leptospirosis worldwide, 1999. Weekly Epidemiological Record 1999; 29: 237-142.

16. WHO. Leptospirosis, India. Weekly epidemiological Record 2000; 27: 217-223.

17. WHO. Onchococerctasis: Strategic direction for Research. 2002; 1. 